\title{
10
}

\section{The Limits of the Influence of International Donors: Social Protection in Botswana}

\section{Isaac Chinyoka and Marianne S. Ulriksen}

\section{Introduction}

Few scholars would question that there has been a "Global Rise of Social Cash Transfers" (Leisering 2019). Since the "quiet revolution" of social protection expansion started in Latin America around the new millennium (Hanlon et al. 2010, 4), social protection programs-be they con-

This chapter draws from the in-depth empirical research presented in Chinyoka (2019).

I. Chinyoka

Centre for Social Development in Africa, University of Johannesburg, Johannesburg, South Africa

e-mail: isaacc@uj.ac.za

M. S. Ulriksen ( $ه)$

Danish Centre for Welfare Studies, University of Southern Denmark, Odense, Denmark

Centre for Social Development in Africa, University of Johannesburg, Johannesburg, South Africa

e-mail:mu@sam.sdu.dk

(C) The Author(s) 2020

C. Schmitt (ed.), From Colonialism to International Aid, Global Dynamics of Social

Policy, https://doi.org/10.1007/978-3-030-38200-1_10 
ditional or unconditional cash transfers, public works, feeding schemes or combinations of these- have spread across the Global South. In many of these countries, the "primary and most consistent advocates of social protection appear to be global actors" (Rudra 2015, 468). It is the transnational actors - multilateral agencies like the World Bank and the United Nations, as well as bilateral ones such as the Department for International Development (DFID)—who have been most enthusiastic about the poverty-reducing potentials of social protection, and it is largely through their encouragement that national governments have adopted social protection programs (Deacon 2007; McCord 2009; Hickey and Seekings 2017).

In reaction to global social policy research, which emphasizes the role of transnational actors with promoting social policy (e.g. Deacon 2007, 2013; Kaasch 2013), there is increasing attention to the importance of domestic politics in sub-Saharan Africa. External organizations cannot merely impose policy ideas but need to link these ideas to national policy processes and to connect with domestic policymakers (Foli 2016; Ulriksen 2019). Social protection policies are unlikely to take off, let alone be maintained, if they do not fit the developmental ideas of national elites or otherwise appeal to key domestic actors (Niño-Zarazúa et al. 2012; Lavers and Hickey 2016; Hickey and Seekings 2017; Hickey et al. 2019). Even in sub-Saharan African countries committed to the adoption of social protection, many of the national governments have been rather unenthusiastic about programs they perceive to have the potential of creating dependency and of imposing a threat to salient values of self-reliance and family kinship (Ulriksen 2019; Seekings 2019). Consequently, elites in sub-Saharan Africa have often, at least initially, resisted the introduction of social protection programs, and as far as they have been persuaded by donors this has been if the proposed policies fitted the strategies and ideas of national elites. ${ }^{1}$

While the social protection reform processes have been incremental and the expansion of coverage slow (even if the number of programs has increased substantially), most African governments have gone along with

\footnotetext{
${ }^{1}$ For instance, in Ethiopia and Rwanda social protection programs are strongly supported by national governments, as they are seen as being important for maintaining political stability and legitimacy (Lavers and Hickey 2016).
} 
the global social protection agenda although there is also a perception that the "global" agenda is dominated by a "Western preoccupation with the rights of individuals" (Seekings 2019, 7). Not so in Botswana. As we argue in this chapter, the welfare policy regime in Botswana has not fundamentally shifted away from its familial focus based on the conservative ideology of the ruling Botswana Democratic Party (BDP), despite various attempts by transnational actors (Seekings, Chap. 5, this volume). As explained elsewhere, welfare policies in Botswana are residual and familyoriented, their main components being workfare for the able-bodied and supplementary feeding schemes for designated vulnerable groups; only selected groups (e.g. orphans) who have ceased to be supported adequately by kin may receive some direct support by the state (in cash and/ or in kind) (Seekings 2016a, c; Ulriksen 2017). Politically, the ruling BDP has been in power since independence in 1966, and although support has declined over time and some political competition has made the BDP introduce broader social protection policies (most noticeably the old age pension of 1996), the party has maintained a strong conservative ethos in policy-making, emphasizing family, self-reliance and hard work (Ulriksen 2012, 2017; Seekings 2016b).

Being today a higher-middle-income country largely independent of international aid, the potential influence of transnational actors may be perceived as being limited. However, there have been pivotal moments when Botswana was extremely reliant on external support, such as during the drought crises of the 1960s (see Seekings, Chap. 5, this volume), during the AIDS pandemic of the 1990s, which hit Botswana particularly hard, as well in the 2010s when transnational actors across sub-Saharan Africa started to promote social cash transfers. In this chapter we focus on the latter two critical moments when one would expect the influence of external actors to be substantial. Furthermore, we concentrate on child welfare policies - the Orphan Care Programme and the non-introduction of a general cash grant-as the well-being of children is an important issue to both the government and transnational actors. Our analysis highlights that although transnational actors have succeeded with persuading the government to change aspects of the Orphan Care Programme, the transnational actors have been unable to fundamentally sway the government to pursue an individual, rights-focused welfare policy paradigm. 
Instead, the government maintains a conservative welfare ideology which centers on the family and self-reliance as important virtues of social security. The case studies are based on an in-depth qualitative analysis presented in more detail in Chinyoka (2019). Before we explore the two cases, we first provide an overview of child welfare policies in Botswana.

\section{Child Welfare Policy in Botswana}

In Botswana, the state plays an active role in providing social protection through investment in goods and services including education, housing, water and sanitation (Nthomang 2007,3). The government funds selfhelp poverty reduction programs particularly in urban areas. The poor, however, rely on kinship care by the family, albeit with limited family capacity, and work-based social provision such as public works programs.

Botswana is a case of a "familial child welfare regime" where public provision for children reflects a primary commitment to the family: Botswana provides transfers in the form of coupons for orphans but not for non-orphaned children, however poor they are; instead, poor families with children are supported through workfare or other (mostly in-kind) payments to adults, and through feeding schemes. The familial primarily in-kind benefits are generous per household but ungenerous per person relative to the national and international poverty lines. Social protection benefits are not based in statutory provisions.

To elaborate, children in Botswana are supported by several programs (see Table 10.1). The Orphan Care Programme (OCP) provides direct benefits for orphans and vulnerable children, reaching about 5 percent of all children in 2013; the OCP transfers were US $\$ 0.90$ per person per day (in December 2017), which is ungenerous relative to the international poverty line of US \$1.90 per day. Children also benefit directly from government school feeding programs, initiated in the mid-1960s and taken over by the government from the World Food Programme in 1997 (see Seekings, Chap. 5, this volume). These are operated at primary and secondary levels, and in some cases from the registration of children's parents as destitute persons. There are special provisions for the children of remote area dwellers (under the Remote Area Development Programme). 


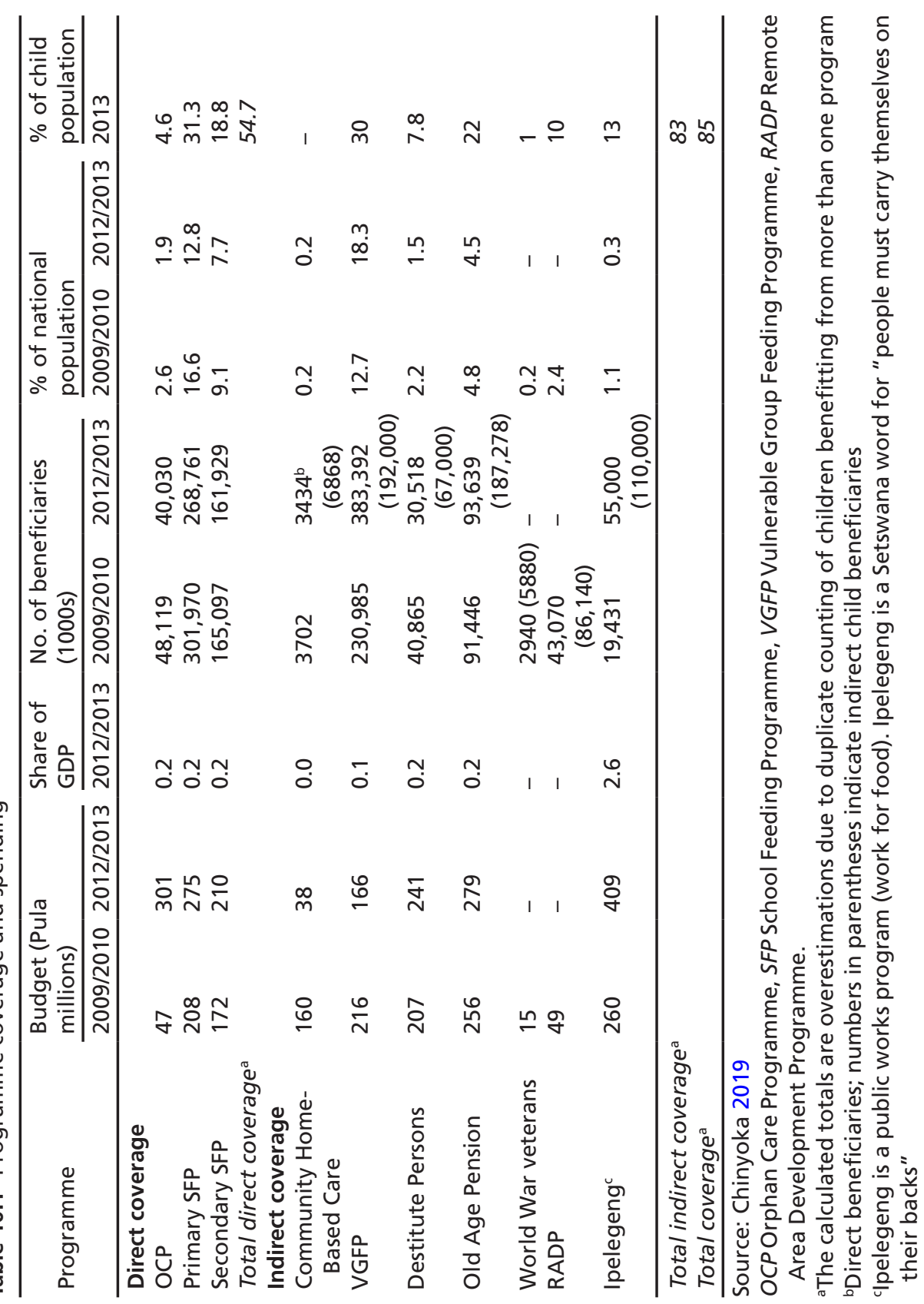


There are a number of other programs where children are indirect beneficiaries, such as the Community Home-Based Care, Vulnerable Group Feeding, Old Age Pensions, Destitute Persons, and Ipelegeng (a public works program). Generally, these programs offer in-kind benefits that are relatively generous and family-based in that beneficiaries receive a familybased food basket/coupon determined by family size. Notable exceptions are the Old Age and World War Veterans pensions which are cash-based benefits, but there are strong expectations that such benefits are shared among families, not least because-partly due to the AIDS pandemic covered in the next section-many children are still taken care of by their grandparents or other elderly relatives (Dahl 2014). The government's provision of family-based benefits reflects the political elite's ideas about reinventing family bonds and the cultural practice of sharing scarce resources, including food, in times of need. Social policy, hence, is rooted in the cultural attributes of kinship (Durham 2007).

In the following, we focus on the OCP (Orphan Care Programme), as this is the only policy directly targeting children; moreover, it was introduced at a pivotal moment when transnational actors played a critical role in Botswana, due to the HIV/AIDS crisis. The main actors in the policy bargaining processes were political elites in government preferring targeted in-kind transfers and workfare programs, UNICEF pushing for the introduction of cash transfers and universalization to include all children, the World Bank supporting poverty targeting and the introduction of cash transfers and the United States Agency for International Development (USAID) advocating for full government funding of all social cash transfers.

\section{Case 1: The Orphan Care Programme}

Since the diagnosis of HIV in Botswana in 1985, the country has continued to have high prevalence rates. In comparison to its Southern African neighbors - South Africa, Namibia and Zimbabwe_-also affected by the advent of HIV and AIDS in the 1990s, Botswana was one of the hardest hit, with high numbers of AIDS-related deaths, triggering an unprecedented increase in "AIDS orphans". A total of 110,000 and 120,000 children 
lost their parents to AIDS in 2003 and 2005, respectively (UNICEF 2005). An estimated 77 percent of registered orphans and 16 percent of all children in 2007 were AIDS orphans (Central Statistics Office 2009b, 55). Many Batswana children grew up "as double orphans, in single parent families or even in child-headed households" (UNICEF 2012, 17).

Festus Mogae, President of Botswana from 1998 to 2008, viewed HIV/AIDS as "the biggest problem facing post-colonial Botswana", as it became an economic and security threat to the nation (Kaboyakgosi and Mpule 2008, 302). The government, in collaboration with international donors, mounted a strong HIV/AIDS intervention, achieving universal access to HIV treatment by the end of 2011 and halving new HIV infections for infants between 2009 and 2012, thereby making important progress toward achieving an AIDS-free society (GoB and UNDP 2010), although "its capacity to sustain the response [was] being stretched to the limit". ${ }^{2}$ Mupedziswa and Ntseane $(2012,60)$ argue that "the pandemic threatened the socio-economic fabric of Botswana society, with breadwinners succumbing to the virus in large numbers, in the process leaving behind thousands of orphans and vulnerable children requiring assistance".

The concern about AIDS orphans prompted the government to prepare and adopt a National AIDS Policy in 1998 to reduce "the impact of HIV/AIDS on society" through, among other activities, "provisions for orphans", reviewing the Destitute Policy "to make special provision for children orphaned due to AIDS" and "to make provision for distressed children of parents infected with HIV as well as those sick with AIDS" (MLG 2006, 3). The following year, the Short-Term Plan of Action (STPA) on Care of Orphans in Botswana was formulated and, based on this, the OCP was initiated to provide orphans with in-kind benefits to cover their immediate basic needs.

The year 1999 was a turning point in the social policy history of Botswana, as the STPA was the first and only policy directly targeting children since independence. The STPA's main objective was "to respond to the immediate needs of orphans, that is, food, clothing, education,

\footnotetext{
${ }^{2}$ UNDP website http://www.bw.undp.org/content/botswana/en/home/countryinfo.html; accessed 30 March 2016.
} 
shelter, protection and care". In keeping with the BDP government's approach of delivering services to the needy, the STPA emphasized that the government will support "community-based responses to the orphan problem" (MLG 1999, 15), suggesting support of the familial and community approaches that existed before the AIDS era (for more details on this see Chinyoka 2019; Seekings 2016a). Although the OCP's ultimate goal was to remove orphans from the poverty trap (Ntseane and Solo 2007, 93), its immediate aim was to "offset the burden of [families/kin] taking on additional mouths to feed" (Dahl 2009, 29). Hence, the OCP promoted kin-based orphan care.

The value of the food basket remained unchanged, with P21,600 per orphan, irrespective of the geographical location of their home from 1999 until 2009. In 2010, the value increased and ranged between P50,000 (US \$41) and P65,000 (US \$76) depending on geographic location (urban, peri-urban or rural). The amount was supposed to be "adjusted for inflation at the beginning of each financial year but it has not been reviewed since 2010 due to affordability concerns, to allow more children to be enrolled on other programmes, particularly the increasing children in need of care (vulnerable children)" and to "direct more financial resources towards income generating projects for families with children to increase their chances of self-reliance" ${ }^{3}$

Donors were influential in the outreach of the OCP. Although the government-PEPFAR ${ }^{4}$ funding partnership was that of a governmentsupported partnership, the pressure to target orphans was unusual for a higher-/middle-income country. This pressure is attributed to the fact that until 2013 OCP was funded by USAID under the PEPFAR program through the National AIDS Coordinating Agency (NACA). Although the government was committed to the OCP, its willingness to financially support the program was absent until the 2010s, and the government took over only in 2014 when it started funding OCP from the ministerial budget. While donors were heavily involved in funding the

\footnotetext{
${ }^{3}$ Quotes from interviews in Gaborone, cf. Chinyoka 2019.

${ }^{4}$ PEPFAR: The President's Emergency Plan for AIDS Relief is an initiative by the US government to address the global HIV/AIDS pandemic and was launched by President George W. Bush in 2003.
} 
OCP, they did not contradict but rather supported the government's narrow targeting of AIDS orphans, which resonated with the BDP's conservative ideology, as we will explain in the following.

From the outset, the OCP is not means-tested; all families with orphans under 18 years are eligible for the program. An orphan is narrowly defined as "a child below 18 years who has lost one (single parents) ${ }^{5}$ or two (married couples, whether married in civil or traditional marriages) biological or adoptive parents". The STPA further defines "social orphans" as "children who are abandoned or dumped or whose parents cannot be traced" (MLG 1999, 9). This definition excluded children living with single parents, such as the mother only but with "absent fathers", who constituted 35 percent and 16 percent of orphans according to a broader definition (see below) in 2001 and 2008, respectively (Central Statistics Office 2001, 2009a).

The orphan definition contrasts with other definitions both within Botswana and internationally. The Botswana Central Statistics Office (now Statistics Botswana) defined orphans as children under 18 years who have lost one or both parents or whose parents' survival status is unknown, while the UNICEF/UNAIDS/USAID $(2002,31)$ state that "an orphan is a child below the age of 18 years who has lost one or both parents". The latter definition was adopted by Botswana's neighbors, South Africa, Namibia and Zimbabwe. The narrow STPA orphan definition applied by the government excludes children falling under the "orphan" category according to the international definition. Thus, in Botswana, a child born out of wedlock can lose one parent through death and will not be regarded as an orphan. For instance, "single" orphans (either maternal or paternal) are not recognized in Botswana. To compel absent fathers to provide for their children, "[d] eserted children born out of wedlock were excluded from the definition of an eligible orphan, and therefore excluded from benefits under STPA unless there was clear proof that the child's father had indeed died" (MLG 2006, 4). As a result of this disparity, orphan rates were estimated at 7 percent and 17 percent in 2008, applying the Botswana and the international definitions, respec-

\footnotetext{
${ }^{5}$ This definition only refers to children who had a single parent and lost that parent through death and excludes children who had two parents (unmarried) and lost one parent through death.
} 
tively (MLG 2008). By accepting the government's narrow definition of orphans, the example reveals the donors' inability to push the government to agree to international standards; the donors also (inadvertently) consented to many children being excluded from the program.

Furthermore, although the OCP was a programmatic response to AIDS and the associated social and demographic changes, its implementation was residual and conservative. It was residual given the narrow definition of orphans and conservative because orphans were supported within a family, indirectly promoting the extended family (familial). Even though some rich families caring for orphans might have benefitted from the OCP since it was not means-tested, many orphans joined their extended families in the rural areas when their parents died, and most of the caregivers were likely to be elderly and poor (Dahl 2014). The livelihoods of these poor caregivers depended on the food baskets and were, like other beneficiaries of food aid for the poor, BDP loyalists (Ulriksen 2017). Overall, Mogae seems to have intensified his response to AIDS, but the response (introduction of the OCP) also buttressed his election campaign for the 1999 elections. Without specifying the strategies to be taken, Mogae underscored that " $\mathrm{t}]$ he BDP will continue to pursue new strategies to mitigate the effects of HIV/AIDS and arrest the spread of the virus". ${ }^{6}$

The government had spearheaded social transfer provision especially to orphans through the STPA, without a major focus on vulnerable children. The exclusion of vulnerable children during the formulation of STPA was, as a result of the plan, being "largely guided by a rapid assessment of orphans" without considering "the distribution and magnitude of problems facing orphans (not to mention other vulnerable children)" (MLG 2006, 6). A 2005 MLG (Ministry of Local Government)UNICEF-supported evaluation concluded that "STPA has managed to reach virtually all eligible orphans with food packages" that "helped to protect not only the nutritional status of the orphans, but also other children in orphan caregiving households, and even caregivers" (MLG 2006, 15). The evaluation established that "orphan" food was shared among

\footnotetext{
${ }^{6}$ BDP 1999 Election Manifesto, p1, accessed 16 August 2015, https://sadcblog.files.wordpress. com/2011/07/bdp-1999-manifesto-botswana.pdf.
} 
family members, suggesting that the OCP basket was already a "family basket" although the government did not initially see it as such. While acknowledging that the move from an orphans to an OVCs (orphans and vulnerable children) orientation was already under way, as some vulnerable children in destitute families were supported under the Destitute Persons Programme, the evaluation recommended that the OCP "move from an orphans focus to an OVC focus" (ibid., 17).

Based on these recommendations, the MLG, supported by USAID/ PEPFAR, commissioned a National Situation Analysis on OVCs in mid-2007. The OVC situation prompted the MLG through the Social and Community Development departments at council level to start registering "vulnerable children" who were not benefitting from any other social assistance programs under the Destitute Persons Programme. A vulnerable child was defined as a "person below the age of 18 years who is in any situation or circumstance which is or is likely to adversely affect the child's physical, emotional, psychological or general well-being, which prevents the enjoyment of his or her rights, and who is in need of protection". The number of registered vulnerable children benefitting and receiving similar support as orphans has been increasing. The number increased from 25,483 in 2008 to 29,033 in 2009 and to a peak of 34,633 in 2010. By October 2015 the number had decreased to 33,681, as more children exited the program compared to entrants. Entrants were few, due to the shortage of social workers who were overwhelmed by other duties than assessing referred children. ${ }^{7}$

Donors played a significant role in advocating for the expansion of support to vulnerable children other than orphans. The 2006 STPA evaluation and the 2008 Situation Analysis on OVCs were primarily funded by UNICEF Botswana and USAID/PEPFAR, respectively. Through the evaluation UNICEF, as an international United Nations (UN) agency advocating for universal coverage of global child social protection, successfully lobbied for a shift among policy-makers from focusing on orphans to including other vulnerable categories. The government recognized the expansion as a way to strengthen disintegrating family structures struggling to provide for children. While the USAID/PEPFAR would

\footnotetext{
${ }^{7}$ Information received in the course of interviews with key stakeholders.
} 
have preferred a continuation of merely orphan-targeting (which reveals some disagreement among donors as will be discussed in the penultimate section), the USAID went along with the government inclusion of other vulnerable categories, as political and financial buy-in of the expansion was important as a part of its exit strategy. At the time of the expansion, the OCP was principally funded by USAID. USAID's strategy was first to have the government enrol vulnerable children on the tax-funded Destitute Persons Programme and later allow the government to take over OCP. While the government immediately adopted the expansion recommendations, it took over OCP funding only in 2013.

The USAID-funded situation analysis on OVCs (orphans and vulnerable children) became "a precursor to the development of a National Policy on Orphans and Vulnerable Children”, still a draft, that would guide the expanded provision of essential services to vulnerable children (GoB 2013). The draft policy is destined to provide an overarching framework to support and guide the delivery of comprehensive, inclusive, "age appropriate, integrated and quality responses to all vulnerable children", contrasting previous OVC responses which tended to separately focus on orphans and other groups of vulnerable children and did not tend to be well guided, coordinated or monitored (GoB 2013). The policy, like Zimbabwe's harmonised social cash transfer, is set to promote a family care approach to the care and support of OVCs. However, the strategic emphasis of the policy on social protection is "targeted interventions and services provided on the basis of assessed needs and vulnerability", presenting both the "government's intention to promote and protect the rights" of Botswana's most vulnerable children and its minimalist approach to social provision for families with children. The proposed policy has gone through two drafts (2009 and 2013) but is - at the time of writing - still awaiting cabinet review, perhaps because the government wants to "discourage dependency" and would rather support OVCs caregivers through employment and self-employment initiatives to strategically limit the number of vulnerable children depending on government support.

The reforms of the OCP to expand the program on vulnerable children indicate a slight but not clear shift to poverty targeting, reflected by the means test (chronically ill or unemployed guardians), but the provi- 
sion remained familial, in that the program targeted no individual children but families with vulnerable children. Furthermore, despite the augmented wider range of "vulnerable" children, many children continued to be excluded from the category because the government remained anxious about both "dependency" and "affordability". The BDP administration expected that the situation of vulnerable children would improve and that the registered numbers would decrease once their parents or caregivers were empowered through poverty eradication programs such as Ipelegeng and other government-funded income-generating activities. According to that view, against all evidence reported by social workers on the deteriorating situation of vulnerable children, the ongoing increase in the number of vulnerable children was considered temporary and did not warrant a stand-alone, long-term policy intervention.

In sum, transnational actors heavily supported AIDS programs in Botswana and were able to push the government to expand the focus from orphans to vulnerable children. However, the donors did not contradict the government's narrow definition of orphans nor its emphasis on family-oriented food baskets. As we shall see in the following, another push by transnational actors was the idea to introduce a social cash transfer.

\section{Case 2: Introduction of Cash Grant Versus Rationalization of the Food Basket}

Like elsewhere on the African continent (and beyond), transnational actors have sought to promote poverty-targeted cash transfers in Botswana as alternatives to the largely in-kind, family-based benefits. However, to no avail. As we explain in the following, the Botswana government rejected, in turn, the proposals coming forth (first for a child support grant [CSG] and thereafter for a family cash-transfer program) and instead adjusted the existing programs fitting its conservative ideology. These proposals came in the context of a poverty-targeted program that would cover all families in absolute poverty being absent; a program that was favored by international actors, particularly UNICEF and the World Bank.

The first proposal by transnational actors was a child support grant (CSG). The process started in 2009-2010 when the government, through 
the Department of Social Services in the Ministry of Local Government (MLG), supported by UNICEF and Regional Hunger and Vulnerable Programme (RHVP), commissioned a countrywide situation analysis and development of a framework for social protection led by a team of international and national social protection experts. The international consultants were led by Frank Ellis, a UK-based social protection specialist whose earlier work in Southern Africa and elsewhere had advocated for universal, rights-based cash transfers. The local consultants were Dolly Ntseane, an academic, seasoned researcher and consultant in social policy and social work, based at the University of Botswana, and Tebogo Seleka, the Executive Director of Botswana's leading independent development policy think tank with a history of poverty reduction strategies (the Botswana Institute for Development Policy Analysis [BIDPA]). The team identified emerging social protection needs for children and developed a Social Development Policy Framework for Botswana (see Devereux et al. 2010; Ellis et al. 2010).

The consultants proposed a CSG with the purpose of "curb[ing] the hunger, malnutrition, social exclusion and other forms of deprivation to which many children are vulnerable, especially in poorer families and most seriously in their pre-school years, with potentially lifelong consequences". Like in South Africa, the CSG "would involve payment of a regular monthly cash grant, (adjusted annually for inflation), to the primary caregivers of children" (Turner et al. 2011, 97) and would cost 1.2 percent of GDP (similar to South Africa) in 2010 (but with the anticipated cost dropping to 0.7 percent by 2020 , as the GDP grew and poverty declined) (Devereux et al. 2010). Anticipated to make a broader-based assault on poverty and "substantially limit the costs of providing emergency relief in the event of shocks and disasters such as drought" (Turner et al. 2011,100 ), the proposed CSG (child support grant) could be introduced incrementally, beginning with the youngest age group (e.g. 0-6 years) and gradually extending it to all those under 18 years. The CSG initial transfer would be set at "P100 per month (with subsequent annual consumer price index linking)" and means-tested "through specifying an appropriate index-linked upper earnings limit for the primary carer and spouse, and/or targeting it to poorer parts of the country, in order to 
concentrate benefits on the most needy" (Ellis et al. 2010, 13). The rationale for the grant was its potential to combat the "vulnerability and inequality that is offered by the patchwork of existing social assistance measures" (ibid., 11).

Despite support from bureaucrats in the Department of Social Protection, who thought the CSG "would reduce the administrative burden of screening deserving children as well as reduce workload for overburdened social workers", ${ }^{8}$ the BDP government rejected the CSG proposal. The cabinet argued against the CSG, as "not every child requires government assistance and universalism will cause dependency and laziness which is against government policy that is encouraging graduation and self-reliance through participation in government funded poverty eradication self-help programmes"?

This view was also expressed by the then President, Ian Khama, who had reminded "the nation at large that ... we need to rekindle our spirit of self-reliance" in his 2009 inauguration address to the National Assembly (Khama 2009, 5). Makgala (2013) argues that the ethos of self-reliance and self-help has been part of the Batswana tradition but was being eroded and replaced by overdependence on the state. Khama's speech seemed determined to preserve this ethos. Continuing with the current narrowly targeted safety nets would reduce excessive reliance on government support at the expense of boipelego (Setswana word for selfreliance). The rejection also reflects the government's view of the poor, that it should only support those that are poor and not able to support themselves and their families through labor. Contrary to evidence from "Mexico's PROGRESA programme and South Africa's CSG", ascertaining that cash transfers "actually reduced dependency by making it possible for recipients to look for and find paid employment" (Devereux et al. 2010, 71; Surender et al. 2010), the Botswana government perceived that introducing the CSG would mean that even the "working poor" families would benefit if their income fell below the established eligibility threshold, which would discourage people from working for their families. UNICEF, RHVP and other partners had sought to provide evidence

\footnotetext{
${ }^{8}$ Interview, cf. Chinyoka 2019.

${ }^{9}$ Interview, cf. Chinyoka 2019.
} 
for the development of "A Social Development Policy Framework for Botswana" to put the CSG on the political agenda but lacked political support from the conservative BDP government that preferred to continue addressing poverty through economic growth rather than introducing a more inclusive child grant.

Perhaps as a strategy to reject the proposed CSG by transnational actors, the government instead pursued a rationalization of the OCP food basket in 2010. Until 2010 each orphan registered under the OCP would receive his or her food ration. A household with three orphans would receive three food baskets. Rationalization implied that a "family" food basket was provided based on the number of household members. In other words, the basket depended on family size rather than eligible individuals, suggesting a further shift from individual to family focus. The food basket per each benefitting household was calculated according to family size and age of household members. Using this formula, one orphan plus two family members were entitled to one food basket, one orphan plus three or four family members would receive one additional food basket and one extra food basket would be allocated for every two additional household members.

This familialist approach was compelled by the government's concern about reported wastage of surplus food especially in houses with many orphans receiving "more than enough", about an increase in the abuse (reselling) of food baskets and about the financial sustainability of the program. There was a need to "rationalise and redistribute" rations from recipient families perceived to be abusing food for other needy groups. The government was aware of the increasing number of OVCs in Botswana (cf. case 1) and realized that many of the households with orphans, who were already receiving a food basket, also included other "vulnerable" children; the government rationalized the food basket to allow both orphans and vulnerable children to benefit from the basket without having to introduce a transfer specific to vulnerable children.

Rationalization also implied a reduction in "destitute" families, as OCP beneficiary households would not qualify for government support under the Destitute Persons Programme. Consequently, it was effective in ensuring that poor families accessed basic needs but created another problem. For, when it came to families that were not considered under 
the Destitute Persons Programme but had rationalized food baskets (because they had orphans), vulnerable children in such households were at risk of falling into destitution or remaining destitute. While "orphan households" benefitted from the food component, vulnerable children in the same households fell short of school fees and other education-related assistance only available to orphans and needy students or children. This exclusion error was a deliberate mechanism, on the part of the government, to reduce the number of poor families depending on government provision; as a government official explained: the rationalization of the program is "working for us". Rather than introducing an unconditional child grant targeting all children under 18 years living in poor families, the government opted for rationalizing the OCP food basket as, complemented by the already rationalized food basket for destitute persons, more poor people were already receiving government support.

Despite the government's rationalization of the food basket and clear rejection of the proposed child cash transfer, transnational actors continued to make proposals. This time attempts were made to better align policy proposals with the BDP's preferences, but the proposals were still rejected. In 2013 the World Bank collaborated with BIDPA to assess Botswana's social protection system, focusing on social assistance programs to inform the country's "future social protection and labour strategy and help achieve the goals of Vision 2016", which encompasses lifting " 84,000 families (336,000 people) from absolute poverty by 2016 " (Tesliuc et al. 2013,3). Even with the existing safety nets, a large number of families were still living in absolute poverty, while the programs, at the same time, drew significantly on the government's budget at a time where "revenues from mining are projected to decline", and hence there was a need to "increase the cost effectiveness of existing programmes" (Tesliuc et al. 2013,3). This could be achieved through "a better weaving of the safety net through the introduction of a last resort, poverty targeted programme": a Family Support Grant (FSG). Such a program would eradicate poverty in a budget-neutral way, as it would be funded from 0.4-0.6 percent of GDP redirected from sponsorships and scholarships programs that accounted for 1.4 percent of GDP in 2012-2013.

The proposed FSG would offer "a benefit of P85 per capita per month (equivalent to P340 for an average family of four) to cover all families 
living in absolute poverty that were not reached by the existing programs in 2013 ". The grant was intended to be implemented gradually, as its design was to be developed in 2013, piloted in 2014 and fully rolled out by end of 2015 (Tesliuc et al. 2013). Three options for the FSG introduction were recommended: the first two options suggested "replacing existing Destitute Persons and Orphan Care programmes with the FSG that would continue to cover poor and lower-middle income families taking care of either orphans or have destitute persons"; the main difference in the two options would be the extent of coverage, the first option being estimated to cover 24 percent of the population and the second option 32 percent of the population. A third option was a "complementary FSG" which entailed offering "P85 per capita per month to all families identified by the proxy-means test as the 24 per cent poorest, but only to family members who are not already covered by other individual, more generous programmes". Beneficiaries of the Destitute Persons, Orphan Care, Old Age Pensions or Ipelegeng programs would be excluded in the third option. Depending on the option taken, the first alternative would be budget-neutral, while options two and three would cost 0.2 or 0.35 percent of the GDP, respectively. The grant was meant to target families in absolute poverty only, and beneficiary households would be selected through a proxy-means test, receive cash benefits and be expected to adhere to conditions, as the government would only provide cash to "poor families contingent on them investing in human capital such as keeping their children in school or regularly taking them to health centres" (Tesliuc et al. 2013, 77).

Although the FSG was to be a family-based poverty-targeted program resonating with the BDP government's preferences for kinship-based benefits, the proposed implementation mechanisms contrasted the BDP's preferred social assistance design. The BDP favored programs that targeted the indigent and provided a safety net as opposed to a povertytargeted grant. The government mistrusted beneficiaries for their abuse of cash benefits, and consequently the World Bank's proposal of a cashbased benefit was met with resistance. A conditional FSG also did not appeal to the BDP administration as, historically, the government did not impose conditions on social allowances. Moreover, if introduced, the grant was considered more "permanent" than most of the safety nets, 
safe for the Old Age Pension and was likely to promote rather than discourage dependency, hence contrasting the principle of self-reliance. The BDP found it "politically difficult" to replace existing programs (options 1 and 2) and seemed concerned about the financial sustainability (option 3) of endorsing the FSG. Olebile Gaborone, Permanent Secretary in the Office of President and Head of the Poverty Eradication Unit, distanced himself and the government from the FSG, saying, "They [donors] are just talking about it and courting us [government] to pilot it but I don't see that happening. We are not part of it at the moment."

In sum, despite evidence suggesting that poverty-targeted cash transfers were more likely to reduce child and household poverty, the BDP rejected the CSG and FSG proposals. The BDP administration prioritized market-based poverty reduction (through labor), with the state providing a safety net largely through in-kind assistance to the "very poor and vulnerable groups in society" (Seleka et al. 2007, 2). These policies reflect the norms of the policy-making political elites within the ruling party. The BDP's preference for self-help contradicts the provision of cash-based support to all poor families with children proposed by international agencies and donors. Hence, these proposals were rejected. "The BDP celebrated rural life, self-help and community, weaving these into a conservative ideology of social justice that decried excessive inequality and legitimated targeted interventions" (Seekings 2016b, 13). The political ideology has perpetuated familial in-kind transfers, preferring modest food rations to cash on the assumption that children will be supported by their working parents or caregivers.

\section{Resistance to Proposals by Transnational Actors}

Why did the government of Botswana resist donor-led proposals for improving child welfare, and how were they able to rebuff the transnational actors' advocacy for broader and individual rights-based programs? Although Botswana is a higher-middle-income country, transnational actors are still important partners to the government in many fields, 
including child welfare policies. Nevertheless, previous research has highlighted how Botswana-together with countries like Ethiopia and Rwanda-has been able to maintain control over its own policy agenda (Whitfield and Fraser 2010). Not only is the political context such that the BDP government experiences relative weak opposition from other political parties and civil society, the bureaucracy is also strong, centralized and professional; the state capacity scores for Botswana ranking among the highest in Africa. ${ }^{10}$

Crucially for our question, Botswana has a tradition of managing aid resources centrally within the Ministry of Finance and of fully integrating them into its own national development plans. The government refused to accept donor-led coordination, such as in the context of Consultative Group meetings, and instead preferred to negotiate with the donors individually (Maipose 2009). Lack of donor coordination is quite common, as donors both compete and cooperate to achieve their goals. However, the centralized domestic management of aid negotiations in Botswana has perhaps further exacerbated the relative weak influence of transnational actors. In our analysis, uncoordinated and competing policy positions were evident in a number of cases. For instance, the transnational actors up to 2013 had conflicting views about the Orphan Care Programme and about whether to continue targeting orphans only or to expand on other vulnerable children, and, with respect to the cash grant, the World Bank showed no support for the otherwise proposed CSG and instead suggested the FSG. Thus, our findings of the limited influence of transnational actors correspond with G. Maipose's conclusion from his study, that "the government has refused aid when it was viewed as not being in the interest of the country, or when it was seen to be incompatible with already identified national priorities" (Maipose 2009, 115).

Having now dealt with the "how" question, we still remain to discuss why the government of Botswana has not been persuaded by the arguments of transnational actors which refer to proven poverty-reducing effects as well as intrinsic values such as the rights of the child. One might be

\footnotetext{
${ }^{10}$ Botswana is the second least corrupt country (https://www.transparency.org/cpi2018) and among the top performers on the world governance indicators (http://info.worldbank.org/governance/wgi/index.aspx\#reports).
} 
tempted to assume that because countries like Ethiopia and Rwanda (otherwise also relatively strong in their negotiations with donors) have adopted social protection schemes, it is because these governments share the same visions as the transnational actors. However, like Botswana, these two countries have not tended to formulate visions for development just to be in line with donor priorities (Whitfield and Fraser 2010; Furtado and Smith 2009; Hayman 2009), and recent in-depth studies indicate that the introduction of social protection schemes is primarily to secure political legitimacy and that Rwanda and Ethiopia share visions of productive development and self-reliance, which also sits well with the conservative ideology present in Botswana (Lavers 2019a, b).

In fact, there are indications that political elites across many African countries adhere to conservative ideas of family, work and dependency (Seekings 2019). Countries like Uganda and Zambia have adopted social protection programs, but there are also debates on welfare dependency and issues of deservingness (Pruce and Hickey 2019; Bukenya and Hickey 2019). A relatively aid-dependent country like Tanzania has also introduced a poverty-targeted conditional cash-transfer program as promoted by donors. Yet, as in the other cases, current research indicates a strong reluctance by the Tanzanian government to fully take over the funding of the program, which is perceived by many as giving free handouts and encouraging laziness and dependency. ${ }^{11}$ Tanzania's founding father, Julius Nyerere, promoted ideas of self-reliance and hard work, and this tradition seems to stick deep (Ulriksen 2019), as does the conservative welfare ideology in Botswana.

\section{Conclusion and Implication of Findings}

This volume focuses on the potential role of external national and transnational actors in driving social policy-making in the Global South, going back as far as to the influence of colonial empires (e.g. Schmitt, Chap. 6, this volume; Künzler, Chap. 4, this volume). The volume also

\footnotetext{
${ }^{11} \mathrm{http} / /$ ps.au.dk/forskning/forskningsprojekter/political-settlements-and-revenue-bargains-inafrica/; M Ulriksen can be contacted for more details.
} 
emphasizes the limits of such external influences, and the case of child welfare policies in Botswana is a good example hereof. Transnational actors had some success with lobbying the government to expand the OCP from being purely orphan-focused to also including vulnerable children but the ultimate goal of introducing a poverty-targeted cash grant was not achieved.

The Botswana government has maintained a conservative welfare ideology even at a time when rights-based cash transfers are promoted globally. Although the government in Botswana has perhaps been more persistent and consistent in following its ideology, and freer to do so, other sub-Saharan African countries also show signs of only reluctant support for the globally appraised social protection floor (Seekings 2019) with a (renewed) interest for values such as self-reliance, hard work and community spirit (Ulriksen 2019; Hickey et al. 2019). This (traditional) emphasis on the collective- the extended family, the community-seems at odds with the rights-based approach entailed in the social protection floors which highlight the rights of individuals toward the state. Consequently, although many African governments have initially accepted social protection programs promoted by transnational actors, the commitment may not stick so deep. The litmus test of the "Global Rise of Social Cash Transfers" lies in its sustainability, based on government funding rather than external support, and some governments-like the one in Botswana-may prefer, and insist on, kinship- rather than rightsbased welfare policies in the long run.

\section{References}

Bukenya, Badru, and Sam Hickey. 2019. The Politics of Promoting Social Protection in Uganda: A Comparative Analysis of Social Cash Transfers and Social Health Insurance. In The Politics of Social Protection in Eastern and Southern Africa, ed. Sam Hickey, Tom Lavers, Jeremy Seekings, and Miguel Niño-Zarazúa. Chapter 8. Oxford: Oxford University Press.

Central Statistics Office. 2001. Population and Housing Census. Gaborone: Government Printers. 
. 2009a. Botswana AIDS Impact Survey (BAIS) III Statistical Report. Gaborone: Government Printers.

- 2009b. Botswana Family Health Survey IV. Gaborone: Government Printers.

Chinyoka, Isaac. 2019. Familial Child Welfare Regimes: The Case of Botswana, 1966-2017. CSSR Working Paper No. 430, University of Cape Town.

Dahl, Bianca. 2009. The "Failures of Culture": Christianity, Kinship, and Moral Discourses about Orphans During Botswana’s AIDS Crisis. Africa Today 56 (1): 23-43.

- 2014. "Too Fat to be an Orphan": The Moral Semiotics of Food Aid in Botswana. Cultural Anthropology 29 (4): 626-647.

Deacon, Bob. 2007. Global Social Policy and Governance. London: SAGE.

- 2013. Global Social Policy in the Making: The Foundations of the Social Protection Floor. Bristol: Policy Press.

Devereux, Stephen, Frank Ellis, Nicholas Freeland, Dolly Ntseane, Janet Seeley, Tebogo Seleka, Stephen Turner, and Philip White. 2010. A Social Development Policy Framework for Botswana. Phase II: Framework and Strategy. Report Commissioned by the Ministry of Local Government of the Republic of Botswana, UNICEF and RHVP. Gaborone: Republic of Botswana.

Durham, D. 2007. Empowering Youth: Making Youth Citizens in Botswana. In Generations and Globalization: Youth, Age, and Family in the New World Economy, ed. J. Cole and D. Durham, 102-131. Bloomington: Indiana University Press.

Ellis, Frank, Nicholas Freeland, Dolly Ntseane, Tebogo Seleka, Stephen Turner, and Philip White. 2010. A Social Development Policy Framework for Botswana. Phase I: Situation Analysis. Report Commissioned by the Ministry of Local Government of the Republic of Botswana, UNICEF and RHVP. Gaborone: Republic of Botswana.

Foli, Rosina. 2016. Transnational Actors and Policymaking in Ghana: The Case of the Livelihood Empowerment Against Poverty. Global Social Policy 16 (3): $268-286$.

Furtado, Xavier, and James Smith. 2009. Ethiopia: Retaining Sovereignty in Aid Relations. In The Politics of Aid: African Strategies for Dealing with Donors, ed. L. Whitfield, 131-155. Oxford: Oxford University Press.

GoB (Government of Botswana). 2013. National Policy on Orphans and Vulnerable in Botswana. Gaborone: Government Printers. 
GoB (Government of Botswana) and UNDP (United Nations Development Programme). 2010. Millennium Development Goals Status Report: Botswana. Gaborone: Government Printers.

Hanlon, Joseph, Armando Barrientos, and David Hulme. 2010. Just Give Money to the Poor: The Development Revolution from the Global South. Sterling, VA: Kumarian Press.

Hayman, Rachel. 2009. Rwanda: Milking the Cow. Creating Policy Space in Spite of Aid Dependence. In The Politics of Aid: African Strategies for Dealing with Donors, ed. L. Whitfield, 156-184. Oxford: Oxford University Press.

Hickey, Sam, and Jeremy Seekings. 2017. The Global Politics of Social Protection. WIDER Working Paper No. 2017/115.

Hickey, Sam, Tom Lavers, Miguel Niño-Zarazúa, and Jeremy Seekings. 2019. The Politics of Social Protection in Eastern and Southern Africa. Oxford: Oxford University Press.

Kaasch, Alexandra. 2013. Contesting Contestation: Global Social Policy Prescriptions on Pensions and Health Systems. Global Social Policy 13 (1): 45-65.

Kaboyakgosi, Gape, and Keneilwe P. Mpule. 2008. Beyond Public Administration? HIV/AIDS Policy Networks and the Transformation of Public Administration in Botswana. Public Administration and Development 28: 301-310.

Khama, Ian. 2009. 2009 Inauguration Address by H.E. Lieutenant General S.K.I. Khama, President of the Republic of Botswana. Gaborone: Government Printing and Publishing Services.

Lavers, Tom. 2019a. Distributional Concerns, the 'Developmental State' and the Agrarian Origins of Social Assistance in Ethiopia. In The Politics of Social Protection in Eastern and Southern Africa, ed. Sam Hickey, Tom Lavers, Miguel Nino-Zarazua, and Jeremy Seekings. Chapter 3. Oxford: Oxford University Press.

. 2019b. Understanding Elite Commitment to Social Protection: Rwanda's Vision 2020 Umurenge Programme. In The Politics of Social Protection in Eastern and Southern Africa, ed. Sam Hickey, Tom Lavers, Miguel Nino-Zarazua, and Jeremy Seekings. Chapter 4. Oxford: Oxford University Press.

Lavers, Tom, and Sam Hickey. 2016. Conceptualising the Politics of Social Protection Expansion in Low Income Countries: The Intersection of Transnational Ideas and Domestic Politics. International Journal of Social Welfare 25 (4): 388-398. https://doi.org/10.1111/ijsw.12210. 
Leisering, Lutz. 2019. The Global Rise of Social Cash Transfers: How States and International Organizations Constructed a New Instrument for Combating Poverty. Oxford: Oxford University Press.

Maipose, G. 2009. Botswana: The African Success Story. In The Politics of Aid: African Strategies for Dealing with Donors, ed. L. Whitfield, 108-130. Oxford: Oxford University Press.

Makgala, Christian John. 2013. Discourses of Poor Work Ethic in Botswana: A Historical Perspective, 1930-2010. Journal of Southern African Studies 39 (1): 45-57.

McCord, Anna. 2009. Cash Transfers and Political Economy in Sub-Saharan Africa. Overseas Development Institute, Project Briefing no. 31.

MLG (Ministry of Local Government). 1999. Short Term of Plan of Action on Care of Orphans in Botswana, 1999-2001. Gaborone: Ministry of Local Government.

. 2006. Final Evaluation Report: Evaluation of the Review of Short Term Plan of Action (STPA) for Orphans in Botswana. Gaborone: Ministry of Local Government.

- 2008. National Situation Analysis on Orphans and Vulnerable Children in Botswana. Gaborone: Government Printers.

Mupedziswa, Rodreck, and Dolly Ntseane. 2012. Human Security in the Southern African Development Community Region: Learning from Botswana's Social Protection Initiatives. Regional Development Dialogue 33 (2): 56-70.

Niño-Zarazúa, Miguel, Armando Barrientos, Samuel Hickey, and David Hulme. 2012. Social Protection in Sub-Saharan Africa: Getting the Politics Right. World Development 40 (1): 163-176. https://doi.org/10.1016/j. worlddev.2011.04.004.

Nthomang, Keitseope. 2007. Provision of Services and Poverty Reduction: The Case of Botswana. Geneva: UNRISD.

Ntseane, D., and K. Solo. 2007. Social Security and Social Protection in Botswana. Gaborone: Bay Publishers.

Pruce, Kate, and Sam Hickey. 2019. The Politics of Promoting Social Cash Transfers in Zambia. In The Politics of Social Protection in Eastern and Southern Africa, ed. Sam Hickey, Tom Lavers, Miguel Nino-Zarazua, and Jeremy Seekings. Chapter 7. Oxford: Oxford University Press.

Rudra, Nita. 2015. Social Protection in the Developing World: Challenges, Continuity, and Change. Politics \& Society 43 (4): 463-470. https://doi. org/10.1177/0032329215602884. 
Seekings, Jeremy. 2016a. Drought Relief and the Origins of a Conservative Welfare State in Botswana, 1965-1980. CSSR Working Paper No. 378, Cape Town, Centre for Social Science Research, University of Cape Town.

- 2016b. "A Lean Cow Cannot Climb Out of the Mud, But a Good Cattleman Does Not Leave It to Perish": The Origins of a Conservative Welfare Doctrine in Botswana under Seretse Khama, 1966-1980. CSSR Working Paper No. 387, Cape Town, Centre for Social Science Research, University of Cape Town.

- 2016c. Building a Conservative Welfare State in Botswana. CSSR Working Paper No. 388, Cape Town, Centre for Social Science Research, University of Cape Town.

- 2019. The Limits of the 'Global' Social Policy: The ILO, the Social Protection Floor and the Politics of Welfare in East and Southern Africa. Global Social Policy. Online Version. https://journals.sagepub.com/ doi/10.1177/1468018119846418.

Seleka, Tebogo B., Happy Siphambe, Dolly Ntseane, Nomtuse Mbere, Charity Kerapeletswe, and Chris Sharp. 2007. Social Safety Nets in Botswana: Administration, Targeting and Sustainability. Gaborone: Lightbooks.

Surender, Rebecca, Michael Noble, Gemma Wright, and Phakama Ntshongwana. 2010. Social Assistance and Dependency in South Africa: An Analysis of Attitudes to Paid Work and Social Grants. Journal of Social Policy 39 (2): 203-221.

Tesliuc, Cornelia, Jose Silverio Marques, Khaufelo Raymond Lekobane, Lilian Mookodi, Anush Bezhanyan, Jeanine Braithwaite, Anna Mohan, Mimi Otsuka, Elina Scheja, Siddarth Sharma, Dolly Ntseane, Sasun Tsirunyan, and Molly Schmalzbach. 2013. Botswana Social Protection Assessment. Pretoria: World Bank \& Botswana Institute for Development Policy Analysis. Turner, Stephen, Philip White, Stephen Devereux, and Nicholas Freeland. 2011. A Child Support Grant for Botswana? In Thari ya Bana: Reflections on Children in Botswana 2011, ed. T. Maundeni and M.S. Nnyepi. Gaborone: UNICEF.

Ulriksen, Marianne S. 2012. Welfare Policy Expansion in Botswana and Mauritius: Explaining the Causes of Different Welfare Regime Paths. Comparative Political Studies 45 (12): 1483-1509.

- 2017. Mineral Wealth and Limited Redistribution: Social Transfers and Taxation in Botswana. Journal of Contemporary African Studies 35 (1): 73-92. 
- 2019. Pushing for Policy Innovation: The Framing of Social Protection Policies in Tanzania. In The Politics of Social Protection in Eastern and Southern Africa, ed. Sam Hickey, Tom Lavers, Miguel Nino-Zarazua, and Jeremy Seekings. Chapter 5. Oxford: Oxford University Press.

UNICEF (United Nations Children's Fund). 2005. Analysis of Child Focused Indicators. Gaborone: UNICEF.

2012. Annual Report 2011. Gaborone: UNICEF.

UNICEF/UNAIDS/USAID. 2002. Children on the Brink 2002: A Joint Report on Orphan Estimates and Program Strategies. Washington, DC: TvT Associates. Whitfield, Lindsay, and Alastair Fraser. 2010. Negotiating Aid: The Structural Conditions Shaping the Negotiating Strategies of African Governments. International Negotiation 15 (2010): 341-366.

Open Access This chapter is licensed under the terms of the Creative Commons Attribution 4.0 International License (http://creativecommons.org/licenses/ by/4.0/), which permits use, sharing, adaptation, distribution and reproduction in any medium or format, as long as you give appropriate credit to the original author(s) and the source, provide a link to the Creative Commons licence and indicate if changes were made.

The images or other third party material in this chapter are included in the chapter's Creative Commons licence, unless indicated otherwise in a credit line to the material. If material is not included in the chapter's Creative Commons licence and your intended use is not permitted by statutory regulation or exceeds the permitted use, you will need to obtain permission directly from the copyright holder.

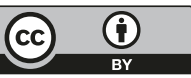

